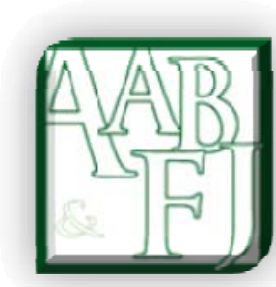

\title{
Director Experience and the Performance of IPOs: Evidence from Sweden
}

Anna Thorsell ${ }^{1}$ and Anders Isaksson ${ }^{2}$

\begin{abstract}
An initial public offering (IPO) represents one of the final stages in the life of a small firm as it transitions from private to public. In this paper the experience of directors is examined to determine the extent of the role they play in ensuring a successful listing. Unique data from 122 IPOs on the Swedish Stock Exchange have been examined in a search for the effect of director experience on aftermarket performance. Specific aspects of director experience within a board, such as interlocking directorships and average tenure, are connected to the underpricing of Swedish IPOs. Contrary to expectations, no statistically significant relationship was found between long-run aftermarket performance and director experience at the time of an IPO. This suggests that the previous experience of directors, as measured in earlier studies, is less relevant to long-term aftermarket performance in Sweden compared to other countries studied in the literature review. This emphasises the importance of examining different institutional contexts.
\end{abstract}

Keywords: Initial Public Offerings, The Board of Directors, Corporate Governance, Underpricing, Aftermarket Performance.

JEL Code: G34

\footnotetext{
${ }^{1}$ Umeå School of Business, Umeå University anna.thorsell@usbe.umu.se

${ }^{2}$ Umeå School of Business, Umeå University \& Chalmers University of Technology anders.isaksson@chalmers.se
} 


\section{Introduction}

The decision to go public is one of the most important decisions made by a small firm. In making that decision, the small firm transforms its operations from the private arena to one of public scrutiny (Certo 2003). A public offering provides the firm with access to the capital needed to finance future growth (Martin 2001; Ou \& Haynes 2006). An initial public offering (IPO) also increases future possibilities to access debt capital (Cressy \& Olofsson 1997). The dependence of all firms on capital for growth is unquestioned, but the changes that are imposed on small firm governance, as a result of the decision to go public, have received only limited attention. Historically, most studies of IPOs have been dominated by traditional finance researchers focused on the existence of underpricing and long-run underperformance of IPOs (Carter et al. 1998). However, given the importance of access to finance for small growth firms, there has been increasing interest among small business researchers in examining the IPO from a small business or entrepreneurship perspective (e.g. St-Pierre 2000; Certo et al. 2001a; Certo et al. 2001b; Ou \& Haynes 2006; Carpentier et al. 2008; Westerman et al. 2008; Zimmerman 2008). Zimmerman (2008) highlighted the importance of the firm's top management team in completing a successful IPO. Westerman et al. (2008) found that venture capitalist backing and stock options for employees had a positive effect on new stock price performance. It would appear that the governance structure of the firm at the time of the IPO, e.g. experienced directors and managers or venture capital involvement, reassures investors who have a limited depth of information about the firm. Most studies of IPOs with small firm focus are concerned with efforts to reduce information asymmetry between the firm and future investors (Daily et al. 2003). Board structure and experienced board membership may substitute for information access, which removes some of the problems inherent in information asymmetry at the time of the offering (Certo et al. 2001a, Certo et al. 2001b).

When transitioning from private to public ownership, corporations make substantial efforts to meet regulatory requirements as well as the expectations of new investors (Filatotchev \& Bishop 2002; Howton 2006; Certo et al. 2009; Bruton et al. 2010). Most of the structural changes in a firm going public are related to corporate governance in general and the board of directors in particular (Certo et al. 2001b; Filatotchev \& Bishop 2002; Baker \& Gompers 2003; Burton et al. 2004). The role of the board, and the firm's utilisation of it, changes throughout the life cycle of the firm (Lynall et al. 2003; Cornelius 2005). The owners' ability to adapt the board of directors to different types of transitions, such as an IPO, could be vital for financial success but the different competencies needed are not necessarily found within the same boards (Söderström 2003). Many researchers have stressed that the structure of the board is a key factor influencing board performance and consequently firm performance (e.g. Daily \& Dalton 1992; Gertner \& Kaplan 1996; Certo et al. 2001a; Howton 2006). However, there is no consensus on an optimal board structure among researchers or practitioners (Gertner \& Kaplan 1996). Empirical research has given inconclusive and mixed results. In this study board structure is extended through the concept of director experience. Specific aspects of experience among the board of directors are examined in relation to aftermarket performance of an IPO; that is, underpricing/initial returns and long-run market performance.

An IPO represents an important milestone in a firm's life cycle, not only changing the capital structure but also bringing increased attention to the firm. The firm must also conform to additional regulations and practices as they move over the threshold from being a private entity to a public one, especially in terms of governance structures (Filatotchev \& Bishop 2002). They generally transition as well from entrepreneurial to professional operating strategies (Daily \& Dalton 1992; Filatotchev 2006). During the complex process of public listing, management is often pre-occupied with non-operational issues for which they are 
often unprepared. In this case a carefully selected and experienced board of directors can be of great assistance to management and ensure a successful listing as well as future high levels of performance (Certo et al. 2001a; Baker \& Gompers 2003; Hartzell et al. 2004). Despite the importance credited to an understanding of governance activities in "threshold" firms, research in this field is still in its infancy (as was stated already in 2006 by Filatotchev).

Previous research on boards of directors and their effect on performance has examined insider/outsider ratios, board size, equity compensation, and other easily accessible factors. The findings have been contradictory both in regard to the effect on performance and on organisational outcomes. For example, Rosenstein and Wyatt (1990) showed that firms appointing outside directors experience an increase in market value while Bhagat and Black (2001) found that firms with more independent boards do not outperform other firms. Filatotchev (2006) reviewed research in this area and concluded that in order to bring the subject of governance and IPOs forward, board experience (and power) should be linked to organisational outcomes or performance. This possible link between board experience and the aftermarket performance of IPOs will be examined herein.

Even though stock pricing patterns following an IPO have proven to be similar all over Europe (Schuster 2003), we have chosen the Swedish market, as it provides us with several research advantages. The Swedish market offers a great opportunity to study an environment that includes a large proportion of small and medium sized enterprises (SMEs). Even though SMEs make up most of the corporations throughout the world they have been neglected in previous studies (Cai et al. 2006). Manually collected data regarding boards and stock prices of corporations listing on the Stockholm Stock Exchange (OMX) between January 1996 and September 2006 have been examined. The OMX consisted of 791 corporations with an average capitalisation of $€ 1,076$ million (total capitalisation $€ 851,459$ million) in 2006 compared to the 2,281 corporations listed on the NYSE with an average capitalisation of $€ 5,217$ million (total capitalisation $€ 11,900,885$ million) (EurIPO Factbook 2007). The average capitalisation of listed corporations on the OMX, being considerably lower than for corporations listed on the NYSE, is, however, similar to those listed on NASDAQ where the average capitalisation in 2006 was $€ 952$ million (EurIPO Factbook 2007).

In addition, the Swedish market is rather unique in the availability of material for study, which allows us to test more variables than examined by previous researchers-several of which have been completely untested in relation to aftermarket performance. The Swedish system of corporate governance combines the shareholder and stakeholder perspectives in a unique way (Kaplan 1998; Brunninge et al. 2007; Thorsell and Cornelius 2009) through the combination of shareholder wealth maximisation and independent boards with employee representation. Furthermore, the Swedish market model, regulated by both government legislative initiatives and the Stock Exchange, forces Swedish firms to comply with what is, in the rest of Europe, classified as voluntary best practice in codes of corporate governance (Kiel \& Nicholson 2003). ${ }^{3}$ The shareholder model is otherwise usually found in Anglo-Saxon countries while the stakeholder model is more commonly applied within Europe.

The rest of the article is organised as follows. Firstly, the pricing and performance of IPOs is discussed, which leads into the hypotheses. The concept of director experience is then examined and defined for the purpose of this article. Director experience is divided into three classes: external ties, intra-corporate experience and specific experience. The data are then presented and analysed, followed by conclusions where the implications of this research and suggestions for further research are discussed.

\footnotetext{
${ }^{3}$ For example, the CEO is not allowed to serve as the chairperson of the board, a minimum number $(50 \%)$ of outsiders is required and all members of the board are required to undertake listing training before an IPO. In addition, the top management team can only be represented by one director.
} 


\section{Pricing and Aftermarket Performance of IPOs}

As a corporation listing for the first time is new to the market there is less historical information about the corporation available to the public than there is for listed corporations. As a consequence, a certain amount of underpricing of initial public offerings is typically expected by investors (Jain \& Kini 1994). It has been suggested that some owners "windowdress" corporations before listing, making them appear more profitable than they actually are to compensate for underpricing. Firms may also inflate the offering price by timing the IPO in a period following unusually good performance (Jain \& Kini 1994). Both "windowdressing" and selective timing of an IPO can lead investors to overestimate pre-IPO performance and underestimate post-IPO performance. It has additionally been suggested that heterogeneous expectations among future shareholders, together with a limited supply of shares, could cause increased underpricing (Gouldey 2006).

Pricing irregularities as well as differences in long term market performance between newly listed and listed corporations have been found in previous empirical research on IPOs (Ritter 1991; Howton et al. 2001; Florin \& Simsek 2007; Certo et al. 2009). Howton et al. (2001), among others, reviewed the research in this area and concluded that on average IPOs outperform the market initially but underperform in total during the first three to four years after listing. Initial underpricing, defined as the extent to which the closing price at the first day of trading differs from the offer price, leads to money being "left on the table" by initial shareholders to the benefit of new shareholders. In addition, the corporation is deprived of funds that could have been utilised within it to ensure future revenues. Filatotchev and Bishop (2002) concluded that certain governance related 'signals', such as retained share ownership by sellers and a board membership that reduces investor anxiety can be used to reduce the extent of underpricing. Experienced board members may lower perceived risks investors attribute to the increased likelihood of agency problems due to the often large reduction of management ownership and block holdings with a subsequent increase in the proportion of minority owners.

As a result of information asymmetries and the risk of long-run underperformance, IPO firms seek ways to signal quality to the market (Certo et al. 2001a; Bruton et al. 2010). Lawless et al. (1998) stated that the most credible quality information regarding the firm's future performance potential is the management (including the board of directors) of the corporation. An experienced board is essential for the performance of the corporation; at the very least it should send a signal to the shareholders and investors of capability and professionalism which would reduce investor uncertainty and consequently increase their valuation of the company. Certo et al. (2001a) argued that the quality of the board is an observable characteristic of the IPO firm, and one where high quality is difficult for corporations of lesser quality to imitate. Directors have their reputations as expert decision makers to protect, which makes them unwilling to participate on the boards of lower quality firms (Fama \& Jensen 1983). As argued by Certo et al. (2001a) and Higgins and Gulati (2003) the board can thus be used as a signal to investors that the firm is structured for high performance. Certo et al. (2001a) stated that if there is a value in having an independent board this should be reflected in the value of the firm's offering price at the time of the IPO. The same argument can be made for other characteristics associated with the board of directors. Hence, if the experience of the directors contributes to the performance of the firm, firms with more experienced directors should be able to sell their shares with less underpricing than firms with less experienced directors. This leads to our first hypothesis.

Hypothesis 1: The more experience found among the directors of the IPO firm the less underpricing of the IPO. 
The long-run aftermarket performance of IPOs has also been subject to debate and, as mentioned above, newly listed corporations tend to underperform in the long run compared to already listed firms (Ritter 1991). Underperformance has been found to vary depending on industry and the period when the corporation is taken public (Ritter 1991). The long-run underperformance of IPO firms is most likely due to the market's inability to correctly evaluate future earnings of previously unlisted firms (Loughran \& Ritter 1995), or to managerial mismanagement due to increased agency problems (Howton et al. 2001). As argued above, a more experienced board should be able to create a stronger long-run aftermarket performance than a less experienced one, hence our second hypothesis.

Hypothesis 2: The more experience found among the directors of the IPO firm the better the long-run aftermarket performance.

\section{Director Experience}

The influence of the experience of directors on firm performance is sparsely considered in previous research. This is probably due to issues of measurability and a shortage of available data. Most researchers focusing on experience in the field of governance have investigated experience in conjunction with the top management team, particularly the CEO. For instance, Filatotchev and Bishop (2002) found executive power and previous experience of executives to have a direct effect on board diversity and non-executive share ownership. They defined experience as management positions and board memberships held over the last five years before the IPO. The expertise of the board per se was investigated in conjunction with the size of the IPO by Finkle (1998) who concluded that the two were positively related. In that study, experience was measured through board size, directors' reputation as university scientists, directors' financial expertise, and directors representing venture capital firms or prestigious underwriters.

The analysis described above, undertaken by Filatotchev and Bishop (2002), generated low R-square values. This is also common in other studies examining the effect of various governance mechanisms on different measures of performance (Certo et al. 2001a; Bhabra \& Pettway 2003). The low values found in previous studies suggest that much remains for further examination. Many factors that may potentially impact firm performance remain to be tested. Filatotchev (2002) suggested that the concept of experience needs to be widened. Because board experience was sparsely considered in previous research, we have drawn upon knowledge from multiple disciplines to widen this concept, as can be seen below. Herein, the concept of director experience has been extended through measurement of external ties (interlocking directorships), intra-corporate experience (founder influence, board tenure and employee representation), and the specific experience of directors (managerial experience, age and venture capitalist involvement).

\section{External Ties}

External ties, such as interlocking directorships, are often discussed under resource dependency theory. Interaction with the external environment is essential to access valuable resources, especially for smaller firms (Pfeffer \& Salancik 1978; Borch \& Huse 1993). Interaction can be, and often is, achieved through the hiring of directors who are also active on other boards. These interlocking directorships provide the firm with information and resources not otherwise available (Pfeffer \& Salancik 1978; Filatotchev \& Bishop 2002) as well as providing legitimacy to the corporation (Huse 2001), which is particularly important for new and small firms. When a director holds interlocking directorships it is a signal that the person is competent, credible and trustworthy (Certo et al. 2001a). Because the reputation 
of directors serving on firms experiencing financial distress suffers, they are unlikely to willingly lend their name to and participate on the board of an IPO firm without having done their own assessment of the firm's quality. Those who err in this judgment are consequently offered fewer board positions in the future (Gilson 1990). The market can, therefore, draw a reasonable inference about the quality of the IPO from the reputation of the directors associated with the firm. Certo et al. (2001a) also concluded that higher reputations among directors are associated with less underpricing. Interlocking directorships should thus lead to less underpricing and better long-term aftermarket performance.

\section{Intra-Corporate Experience}

Founders. The founder of a corporation has significant insight into the firm's operations as well as an emotional stake and often large financial interests in the business. Cowling (2003) argued that a founder provides valuable input into firm operations and holds a unique position in terms of power. Howton (2006) found that if the CEO is a founder, the corporation will outperform non-founder led corporations. Because the board is one of the most important governance mechanisms of the firm, having the founder among the board members should also be valuable to the firm and affect both underpricing and long-term aftermarket performance. The presence of the founder on the board should thus influence the corporation in similar ways as if he or she were the CEO of the corporation.

Board tenure. The more time a member of the board has spent on one specific board the more knowledge he or she would have of the internal workings of the corporation. This would also result in increased knowledge about how to utilise this experience within the board in question. Previous findings by Howton (2006) have shown that longer tenure among board members (the average in her study being 7.38 years) is significantly related to firm survival. This is also supported by Crutchley et al. (2002) who found that board stability increases aftermarket performance.

Employee representation. Employee representation on the board is found in, for instance, Germany, The Netherlands, Finland, and Scandinavian countries. In Sweden, legislation stating the right of employees to be a part of the board of corporations was passed as early as 1973 (Levinson 2001). The motivation behind this legislation was to give the employees greater insights into the corporation as well as some influence over its operations. However, the effect on performance for those companies having employee representation on the board has, to the best of our knowledge, never been examined. Levinson (2001) asked Swedish managing directors and chairpersons about their view on employee representation. The majority (more than 65\%) viewed employee representatives as a valuable resource for the corporation. The representatives are said to contribute to a positive co-operative climate and stronger support among employees for board decisions.

\section{Specific Experiences}

Managerial experience. The presence or non-presence on the board or in the top management team of someone with managerial experience is often discussed in conjunction with new ventures and SMEs. In smaller firms the board is often called upon to make up for the lack of managerial experience and expertise within the firm (Huse 1990; Daily \& Dalton 1992). Moy and Luk (2003) concluded that this shortage in experience among top managers is an obstacle for growth in SMEs. Because many firms going public for the first time are classified as SMEs the managerial experience among upper echelons could be an issue. Board members with CEO experience will have insights and knowledge about how to manage a firm as well as insights into certain industries. As with interlocking directorships, there may 
also be a valuable network to be utilised by the firm if board members are or have been CEOs of other firms.

Director age. In labour research it has long been recognised that with age comes growing labour market experience resulting in a growth in earnings for the employing firm (Medoff \& Abraham 1980). In addition, it has been suggested that older directors, besides experience, also provide wisdom, possibly economic resources (Kang et al. 2007), and a higher level of maturity and moral development (Daboub et al. 1995) than do younger directors. Muth and Donaldson (1998:8) argued that "boards of a higher average age may exhibit a conservative bias and better judgment. Therefore they may be more capable of thinking independently and more likely to control younger managers inclined to take risks at the expense of shareholders." In support of these arguments Bodnaruk et al. (2008) found younger owners more eager to take their corporation public with the firms consequently more underpriced. Considering these arguments, the average age of directors should have an effect on aftermarket performance.

Venture capitalist involvement. Venture capital firms specialise in co-investing equity with the entrepreneurs to fund high growth firms. Doing that implies that they need to not only contribute with growth capital, but also with the necessary competence to help the entrepreneurial firm to grow (Isaksson 2006). Hence, venture capitalists take an active role in the firms in which they invest (Fried \& Hisrich 1995). They provide support and governance, for example, by active participation on the board of directors, acting as a sounding board, monitoring financial performance etcetera (Gorman \& Sahlman 1989; Sapienza \& Timmons 1989; MacMillan et al. 1989; Ehrlich et al. 1994). Furthermore, Gabrielsson and Huse (2002) showed that boards in venture capital backed firms were more active than boards in other firms (for instance by higher frequency of meetings).

An IPO is one of the most preferred exit mechanisms for venture capitalists (Cumming $\&$ MacIntosh 2002). Several studies have investigated how venture capital backed firms perform after an IPO or the issue of over or underpricing of shares at that time (Barry et al. 1990; Megginson \& Weiss 1991; Lerner 1994; Bruton et al. 2010). For example, Barry et al. (1990) investigated underpricing in connection with venture capitalists and found that due to the expertise and guidance provided by the venture capitalist the corporations were less underpriced than corporations not backed by a venture capitalist. They found that venture capital backed IPOs hired more distinguished underwriters and were introduced at lower Price/Earnings ratios. Lerner (1994) also examined the contribution venture capitalists made to the success of an IPO of the firms in their portfolios. While his study was limited to 350 biotech companies, he found that venture capital backed companies usually made their IPO at higher market values than companies without venture capital backing. Brav and Gompers (1997) also showed that the specific experience possessed by venture capitalists have an effect on the performance of the corporation (in other words, that venture capital backed firms outperform non-venture capital backed firms due to the continued presence of venture capital firm representatives on the board).

Hence, the managerial experience of venture capitalists as well as their experience of previous public listings indicates that there should be a positive effect on aftermarket performance in venture capital financed firms going public. 


\section{Data, Variables and Descriptive Statistics}

Data

In order to test these hypotheses, the total population of IPOs listed on the Stockholm Stock Exchange (OMX) over a ten year period (January 1996-September 2006) was investigated. During this time period there were approximately 260 new listings on the OMX and of these approximately 130 were initial public offerings as described by OMX classifications. Basic information regarding these IPOs, such as listing price, date, industry sector and size of listing, was retrieved from the OMX. To learn more about these IPOs, prospectuses were collected either from the companies themselves, various underwriters, or public authorities. For this study it was possible to assess $94 \%$ of the prospectuses of IPOs that occurred during the time period selected for examination. The rest of the IPOs occurring in this period $(6 \%)$ have been excluded due to changes in organisational form, such as buyouts, reorganisations, or mergers and acquisitions, which limited access to relevant material. Data regarding

\section{Table 1. Variables Description}

This Table contains descriptions of the variables used in the analysis. Column one gives the category of the variable as well as an extended name. The abbreviated name used in the analysis is given in column two, while the third column has a brief description of each variable.

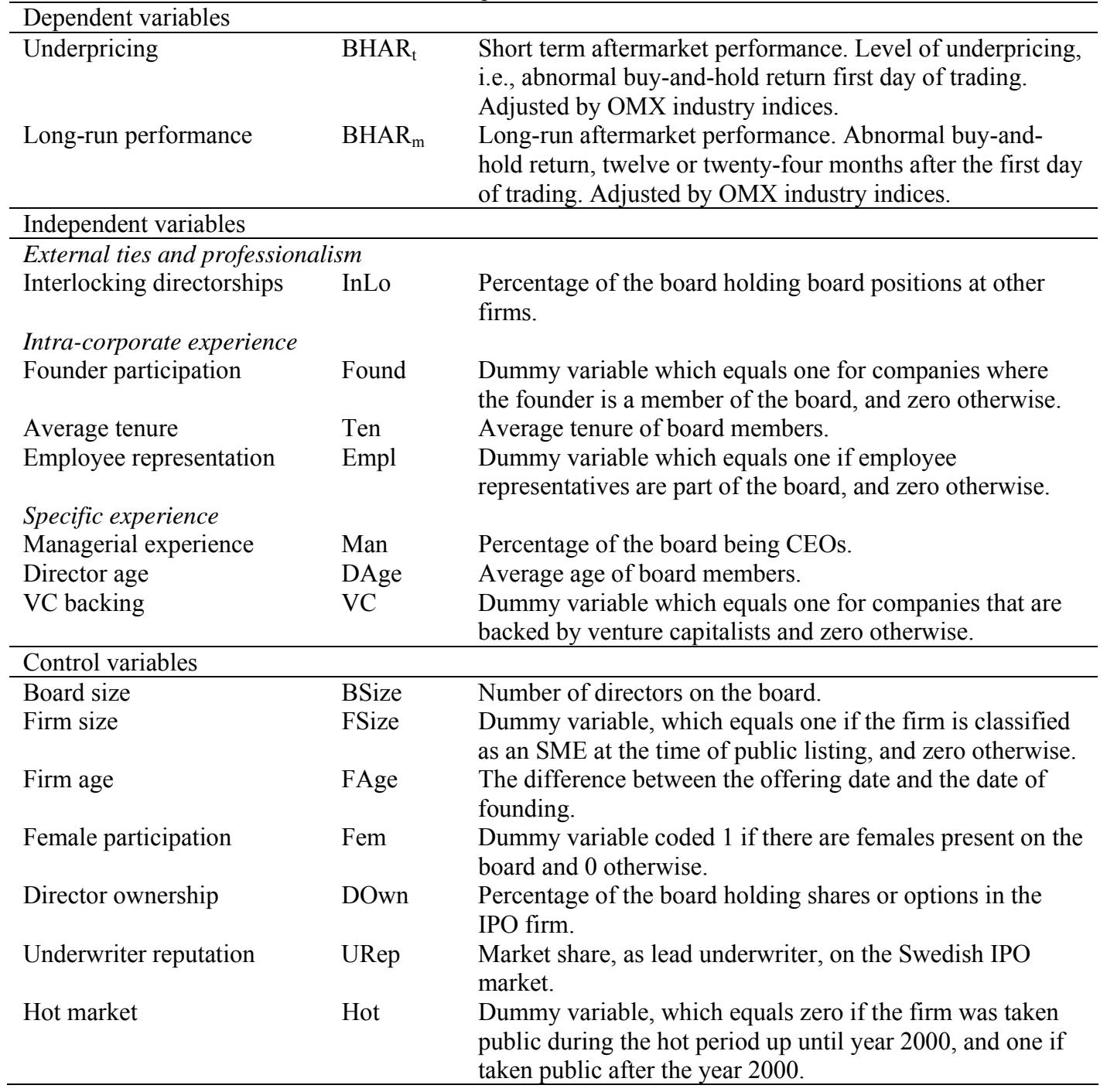


accounting information were compiled from the prospectuses from the latest annual report at the time of the IPO. Any information available in the prospectuses regarding the experience of the directors was also compiled.

In order to test the hypotheses, information regarding the daily stock price of each IPO up until twenty-four months after the listing was also collected from Thomson DataStream. Market adjustments of the returns were made using the OMX Global Industry Classification Standard (GICS) sectoral indices. This information was retrieved directly from the Stock Exchange. Information on venture capitalists' involvement was retrieved from the database of Förvärv \& Fusioner AB, a well-respected agency conducting research on mergers and acquisitions in Sweden. This information was then matched with the database on IPOs created for this study.

\section{Variables}

A full list of the variables assessed as well as brief descriptions of each are given in Table 1 . The independent variables, derived from section 3, are self-explanatory while the dependent variables as well as the control variables are described below. To adjust for skewness, and to accommodate the normality assumption on which regressions are built, natural logarithmic transformations were applied to several of the variables before analysis as indicated by "ln" before the variable name below in Table 3 and 4.

Dependent Variables. To evaluate the aftermarket returns, three time periods were examined: underpricing and long-run aftermarket performance after twelve and twenty-four months, all measured as buy-and-hold abnormal returns. The measures utilised in this study are among the most common when examining aftermarket performance of IPOs (Certo et al. 2009). Underpricing measures the extent to which the closing price at the first day of trading differs from the offer price. The level of underpricing has been market adjusted as proposed by Carter et al. (1998) and Certo et al. (2001b) and is calculated as the percentage increase from the offering price to the closing price on the first day of trading. Returns are then adjusted by subtracting the increase in OMX Global Industry Classification Standard (GICS) sectoral indices during the same time period (for industry classes and indices see Appendix A). Hence, the level of underpricing for stock $i$ for period $t, \mathrm{BHAR}_{t}$, is calculated as:

where

$$
\text { BHAR }_{i, t}=R_{i t}-R_{s(i) t},
$$

$$
R_{i t}=P_{i, t} / P_{i, t-1}-1 \quad \text { and } \quad R_{s(i) t}=S_{i, t} / S_{i, t-1}-1
$$

$P_{i, t}$ is the closing price of the stock $i$ on its first trading day, $P_{i, t-1}$ is its offering price, $S_{i, t}$ is the closing index (for the stock $i$ sector), and $S_{i, t-1}$ is the opening index for that trading day. Long-run aftermarket performance is calculated as abnormal buy-and-hold returns after the first day of trading, and is measured over twelve $(m=12)$ and twenty-four $(m=24)$ months after the IPO. ${ }^{4}$ Using two different time periods when measuring long-run performance enables examination of time-varying performance patterns. Hence, the abnormal long-run aftermarket performance $\left(\mathrm{BHAR}_{\mathrm{m}}\right)$, over either twelve or twenty-four months, for stock $i$ is calculated using the same general pattern as above, where:

$$
R_{i t}=P_{i, t+m} / P_{i, t}-1 \quad \text { and } \quad R_{s(i) t}=S_{i, t+m} / S_{i, t}-1 .
$$

\footnotetext{
${ }^{4}$ For a more in depth discussion about buy-and-hold returns see Bhabra and Pettway (2003).
} 
$P_{i, t+m}$ is the closing price of stock $i$ after twelve or twenty-four months, $P_{i, t}$ is the closing price of stock $i$ day one. By using the closing price from day one underpricing is excluded from the measure as is done in most studies on long-run performance of IPOs (Loughran \& Ritter 1995). $S_{i, t+m}$ is the closing price of the GICS index for industry $i$ after twelve or twenty-four months, and $S_{i, t}$ is the closing price of the index for the first trading day of the stock. It is also common to adjust returns using benchmark firms, as described in Loughran and Ritter (1995). However, as argued by Brav and Gompers (1997), market adjustment using industry indices avoids the possible bias caused by firm specific events in benchmark firms while consideration is given to events that have an effect on the returns of an entire industry.

The dependent variables included some extreme observations. In order to neutralise the effect of these outliers in the continuing analysis the sample was Winsorized (Tukey 1962; Armstrong 2001; Jose \& Winkler 2007). The most extreme observations (two percent highest and lowest values) were replaced by the nearest unaffected values. As argued by Tukey (1962) this method is preferable to trimming of data since that would reduce the efficiency of the analysis, especially when outliers are not the result of data collection or sampling errors.

Control Variables. Previous researchers have found that a number of governance variables, other than those mentioned above, influence firm performance. These variables include board size, director ownership in the firm, gender diversity (female directors present on the board), underwriter reputation, firm age and size and year of introduction. All are also included in this analysis. Various scholars (Yermack 1996; Eisenberg et al. 1998; Certo et al. 2001a; Howton et al. 2001) have investigated board size and its influence on performance. Their results have been inconclusive. Firm size and age also have a reported relationship to firm performance (Jain \& Kini 1994; Ritter 1998; Bhabra \& Pettway 2003). For instance, Bhabra and Pettway (2003) have found that the underperformance of IPO firms in relation to already listed firms is more severe for smaller and younger firms. In this research, firm size is measured through a dummy coded 0 for large firms and 1 for small and middle-sized firms as defined by European Union classifications. ${ }^{5}$ Age of the firm is measured as the difference between the offering date and the date of founding.

Sweden has, during the last decade, been under pressure to increase female participation in managerial and board positions. Boards in Sweden have become more gender diverse during the last couple of years (Thorsell \& Cornelius, 2009). It is expected that greater gender diversity will broaden the available pool of director talent and thus increase board effectiveness (Higgs 2003). Due to the marginal number of female directors during the period examined (only $6 \%$ ) the influence of female participation is tested using a dummy variable coded 0 if there are no females on the board and 1 otherwise.

Research on governance has been focused largely on the incentives of board and management to work in the interest of shareholders. Directors are given incentives, through share holdings or options in the company, in order to align their interests with those of shareholders. This is meant to encourage them to work more effectively toward better market performance (Howton et al. 2001; Filatotchev \& Bishop 2002). The percentage of directors holding shares or options (or both) in the corporation has therefore been added as a control variable.

The reputation of the lead underwriter may also impact the investors' valuation of the firm (Carter et al. 1998; Howton 2006). Future business for underwriters is largely based on the success of previous undertakings. It is thus in the best interest of the underwriters that the IPOs they manage are successful. Underwriters do, in addition, possess valuable experience

\footnotetext{
${ }^{5}$ Within the EU, SMEs are defined as corporations with 10-249 employees and an annual turnover not exceeding EUR 50 million, and/or an annual balance sheet total not exceeding EUR 43 million (The Commission of the European Communities 2003).
} 
based on taking part in several previous IPOs. Underwriter reputation is based on market share as primary underwriter in the Swedish IPO market. This approach is similar to that employed by Megginson and Weiss (1991:890) who assumed that "the greater the average market share of the lead underwriters, the higher is the quality". Market share can be calculated either through the percentage of the value of the shares being introduced on the market or the actual number of IPOs. The value offered to the market by each firm has not been calculated in the same way for the IPOs in our study. Therefore, the percentage number of IPOs brought to the market is used to calculate the market share, as in Bodnaruk et al. (2008).

The level of underpricing has proven to be higher in hot markets (Florin \& Simsek 2007), thus making the year of introduction important. The Swedish market experienced such a period, as did most western markets, during the late 1990's until the so-called IT-bubble collapsed in 2000. A dummy has thus been created coded 1 for the more pessimistic market environment following the burst of the IT-bubble in 2000 and 0 for the bull-market years leading up to this event (1996-2000).

\section{Descriptive Statistics of Variables}

Descriptive statistics are presented in Table 2. Table 3 contains a correlation matrix of all analysed variables. The descriptive statistics show that the average underpricing in the Swedish IPO market is quite large; $15 \%$ for the first day of trading. This result is similar to that of previous research on underpricing (Ritter 1991) and almost identical to previous studies of Swedish IPOs: Schuster (2003) reported 18.5\% and in Bodnaruk et al. (2008) reported $14.2 \%$. After the first day of trading, the IPO firms included in this study on average

Table 2. Descriptive Statistics of Variables

This Table contains descriptive statistics for the assessed dependent and independent variables (before natural logarithmic transformations). The mean, standard deviation, minimum, median and maximum of the dependent, independent and control variables are reported. For dummy variables further descriptive statistics are provided in Appendix B.

\begin{tabular}{|c|c|c|c|c|c|}
\hline Variables & Mean & $\mathrm{SD}$ & Minimum & Median & Max \\
\hline \multicolumn{6}{|c|}{ Dependent variables } \\
\hline $\mathrm{BHAR}_{\mathrm{t}}$ & 0.150 & 0.309 & -0.213 & 0.070 & 2.404 \\
\hline BHAR $_{12}$ & 0.193 & 1.530 & -2.177 & -0.101 & 10.852 \\
\hline $\mathrm{BHAR}_{24}$ & 0.008 & 1.054 & -3.056 & -0.106 & 4.549 \\
\hline \multicolumn{6}{|c|}{ Independent variables } \\
\hline InLo & 73.575 & 22.071 & 0.000 & 80.000 & 100.000 \\
\hline Found & 0.517 & 0.502 & 0.000 & 1.000 & 1.000 \\
\hline Ten & 3.888 & 2.644 & 0.000 & 3.330 & 12.400 \\
\hline Empl & 0.310 & 0.466 & 0.000 & 0.000 & 1.000 \\
\hline Man & 48.783 & 23.246 & 0.000 & 50.000 & 100.000 \\
\hline DAge & 50.845 & 4.403 & 38.670 & 51.430 & 60.800 \\
\hline $\mathrm{VC}$ & 0.431 & 0.497 & 0.000 & 0.000 & 1.000 \\
\hline \multicolumn{6}{|c|}{ Control variables } \\
\hline BSize & 5.877 & 1.125 & 3.000 & 6.000 & 9.000 \\
\hline FSize & 0.575 & 0.496 & 0.000 & 1.000 & 1.000 \\
\hline FAge & 29.016 & 32.615 & 1.000 & 13.000 & 147.000 \\
\hline Fem & 0.240 & 0.429 & 0.000 & 0.000 & 1.000 \\
\hline DOwn & 64.466 & 33.411 & 0.000 & 71.400 & 100.000 \\
\hline UWRep & 0.162 & 0.092 & 0.008 & 0.171 & 0.285 \\
\hline Hot & 0.179 & 0.385 & 0.000 & 0.000 & 1.000 \\
\hline
\end{tabular}


Table 3. Correlation Matrix

This Table contains the Pearson correlation for all analysed variables. ${ }^{*} \mathrm{p} \leq .10 ; * * \mathrm{p} \leq .05 ; * * * \mathrm{p} \leq .01$ (2-tailed)

\begin{tabular}{|c|c|c|c|c|c|c|c|c|c|c|c|c|c|c|c|c|}
\hline & $\mathrm{BHAR}_{\mathrm{t}}$ & $\mathrm{BHAR}_{12}$ & $\mathrm{BHAR}_{24}$ & InLo & Found & $\operatorname{lnTen}$ & Empl & lnMan & lnDAge & $\mathrm{VC}$ & lnBSize & lnFAge & Fem & DOwn & lnUWRep & Hot \\
\hline BHARt & 1 & & & & & & & & & & & & & & & \\
\hline BHAR $_{12}$ & 0.055 & 1 & & & & & & & & & & & & & & \\
\hline $\mathrm{BHAR}_{24}$ & 0.142 & $\begin{array}{r}0.688 \\
* * *\end{array}$ & 1 & & & & & & & & & & & & & \\
\hline InLo & $\begin{array}{r}-0.177 \\
* *\end{array}$ & 0.045 & -0.029 & 1 & & & & & & & & & & & & \\
\hline Found & 0.114 & -0.107 & -0.138 & -0.137 & 1 & & & & & & & & & & & \\
\hline $\operatorname{lnTen}$ & 0.119 & 0.135 & $\begin{array}{r}0.166 \\
*\end{array}$ & -0.120 & 0.093 & 1 & & & & & & & & & & \\
\hline Empl & 0.024 & 0.047 & 0.158 & -0.119 & $\begin{array}{r}-0.170 \\
*\end{array}$ & 0.140 & 1 & & & & & & & & & \\
\hline $\operatorname{lnMan}$ & 0.041 & -0.051 & -0.081 & 0.031 & 0.115 & -0.071 & 0.033 & 1 & & & & & & & & \\
\hline lnDAge & -0.042 & 0.070 & 0.140 & 0.068 & -0.147 & $\begin{array}{r}0.190 \\
* *\end{array}$ & 0.124 & -0.090 & 1 & & & & & & & \\
\hline VC & 0.011 & 0.022 & -0.009 & 0.126 & 0.125 & 0.010 & 0.024 & 0.065 & -0.035 & 1 & & & & & & \\
\hline $\ln B$ Size & -0.011 & 0.041 & 0.043 & 0.012 & $\begin{array}{r}-0.209 \\
* *\end{array}$ & 0.076 & $\begin{array}{r}0.581 \\
* * *\end{array}$ & 0.106 & 0.102 & $\begin{array}{r}0.149 \\
*\end{array}$ & 1 & & & & & \\
\hline lnFAge & -0.120 & $\begin{array}{r}0.176 \\
*\end{array}$ & $\begin{array}{r}0.176 \\
*\end{array}$ & 0.026 & $\begin{array}{r}-0.430 \\
* * *\end{array}$ & $\begin{array}{r}0.270 \\
* * *\end{array}$ & $\begin{array}{r}0.302 \\
* * *\end{array}$ & -0.020 & $\begin{array}{r}0.289 \\
* * *\end{array}$ & -0.049 & $\begin{array}{r}0.257 \\
* * *\end{array}$ & 1 & & & & \\
\hline Fem & 0.002 & 0.018 & 0.026 & -0.109 & -0.118 & -0.042 & -0.005 & 0.106 & 0.041 & -0.096 & $\begin{array}{r}0.194 \\
* *\end{array}$ & $\begin{array}{r}0.260 \\
* * *\end{array}$ & 1 & & & \\
\hline DOwn & $\begin{array}{r}0.156 \\
*\end{array}$ & -0.049 & $\begin{array}{r}-0.183 \\
*\end{array}$ & -0.107 & $\begin{array}{r}0.412 \\
* * *\end{array}$ & 0.091 & $\begin{array}{r}-0.185 \\
* *\end{array}$ & -0.026 & -0.128 & 0.024 & $\begin{array}{r}-0.252 \\
* * *\end{array}$ & $\begin{array}{r}-0.371 \\
* * *\end{array}$ & $\begin{array}{r}-0.168 \\
*\end{array}$ & 1 & & \\
\hline $\begin{array}{l}\ln U W R e \\
\mathrm{p}\end{array}$ & 0.072 & 0.157 & 0.088 & $\begin{array}{r}0.333 \\
* * *\end{array}$ & 0.030 & 0.015 & -0.051 & 0.129 & 0.177 & -0.026 & 0.145 & -0.069 & -0.024 & 0.059 & 1 & \\
\hline Hot & $\begin{array}{r}-0.176 \\
* *\end{array}$ & 0.056 & 0.009 & 0.145 & -0.103 & 0.038 & -0.042 & 0.092 & 0.068 & $\begin{array}{r}0.194 \\
* *\end{array}$ & $\begin{array}{r}0.233 \\
* * *\end{array}$ & 0.103 & $\begin{array}{r}0.388 \\
* * *\end{array}$ & -0.079 & $\begin{array}{r}0.191 \\
* *\end{array}$ & 1 \\
\hline
\end{tabular}


outperformed the market by $19 \%$ in the first year followed by a year of modest aftermarket performance $(0.8 \%)$. It can also be seen, that the underperformers are increasingly underperforming over time while the firms with the largest growth in market value have peaked at twelve months. In contrast with previous findings in Anglo-American research (Ritter 1991) the IPO firms in this study have not underperformed the market on average during this period of time. Previous studies using Swedish data have given similar results to ours (Loughran et al. 1994, Schuster, 2003). In fact, Loughran et al. (1994) reported long-run aftermarket over-performance by Swedish listed corporations.

It is shown, in Table 2, that on average, $70 \%$ of the directors included in the study held interlocking directorships while almost $50 \%$ had managerial experience. On average a director in a Swedish IPO firm is male and 51 years old, $43 \%$ of the firms in the sample are backed by venture capitalists, and 50\% have a founder that is a member of the board. Even though employees are legally encouraged to participate in board activities, only $30 \%$ of the firms have boards with employee representation.

Descriptive statistics on control variables show that IPOs in hot markets are overrepresented by $82 \%$ of the firms during the period sampled. When it comes to size the firms are a bit more evenly distributed with $69 \%$ classified as small or middle-sized. The firms are on average surprisingly old, 29 years. However, this number appears to be influenced by a small number of older firms, particularly one that is 147 years old; the median is substantially lower at 13 years. As previously indicated the number of females on Swedish IPO boards is low and only $24 \%$ of the firms have a board with at least one female director. Director ownership and/or stock options given to directors appear to be very common. The boards consist of 6 members on average (6.5 when personnel representatives are included).

\section{Results}

The relationship between various measures of board experience and the aftermarket performance of the IPO firm has been tested through OLS regressions. Each dependent variable, underpricing and long-run aftermarket performance (twelve or twenty-four months) have been tested individually through the following general form:

$$
B H A R_{i}=\alpha+\beta_{1} x_{1 i}+\ldots+\beta_{n} x_{n i}+\varepsilon_{i}
$$

Where $B H A R_{i}$ is the buy-and-hold abnormal return for stock $i, \alpha$ is the constant and $\varepsilon$ the error term. $\beta_{1}$ through $\beta_{n}$ are the estimated coefficients for each independent and control variable; $\mathrm{x}_{1}$ through $\mathrm{x}_{n}$. Outliers were removed based on standardized residuals.

By the Pearson correlations (2-tailed) reported in Table 3 it is evident that there may be some collinearity between several of the independent variables as well as the control variables. As a consequence multicollinearity diagnostics were calculated. The highest variance inflation factor (VIF) was 2.0 for board size, which is well below the threshold value of 10 . These results indicate that the levels of multicollinearity are insignificant.

\section{Underpricing}

The estimated coefficients shown in Table 4 indicate that only two of the measures of director experience have a significant effect on the level of underpricing of Swedish IPOs; interlocking directorships and average tenure. The higher the percentage of board members with interlocking directorships the lower the underpricing among those firms examined. This 
Table 4. Effects of Director Experience on Underpricing and Long-Term Performance

This table reports the results of the OLS regression. Coefficients are standardized beta estimates. All regressions contain an unreported constant. T-values are given in brackets. "In" before the variable name indicates where natural logarithmic transformations have been applied.

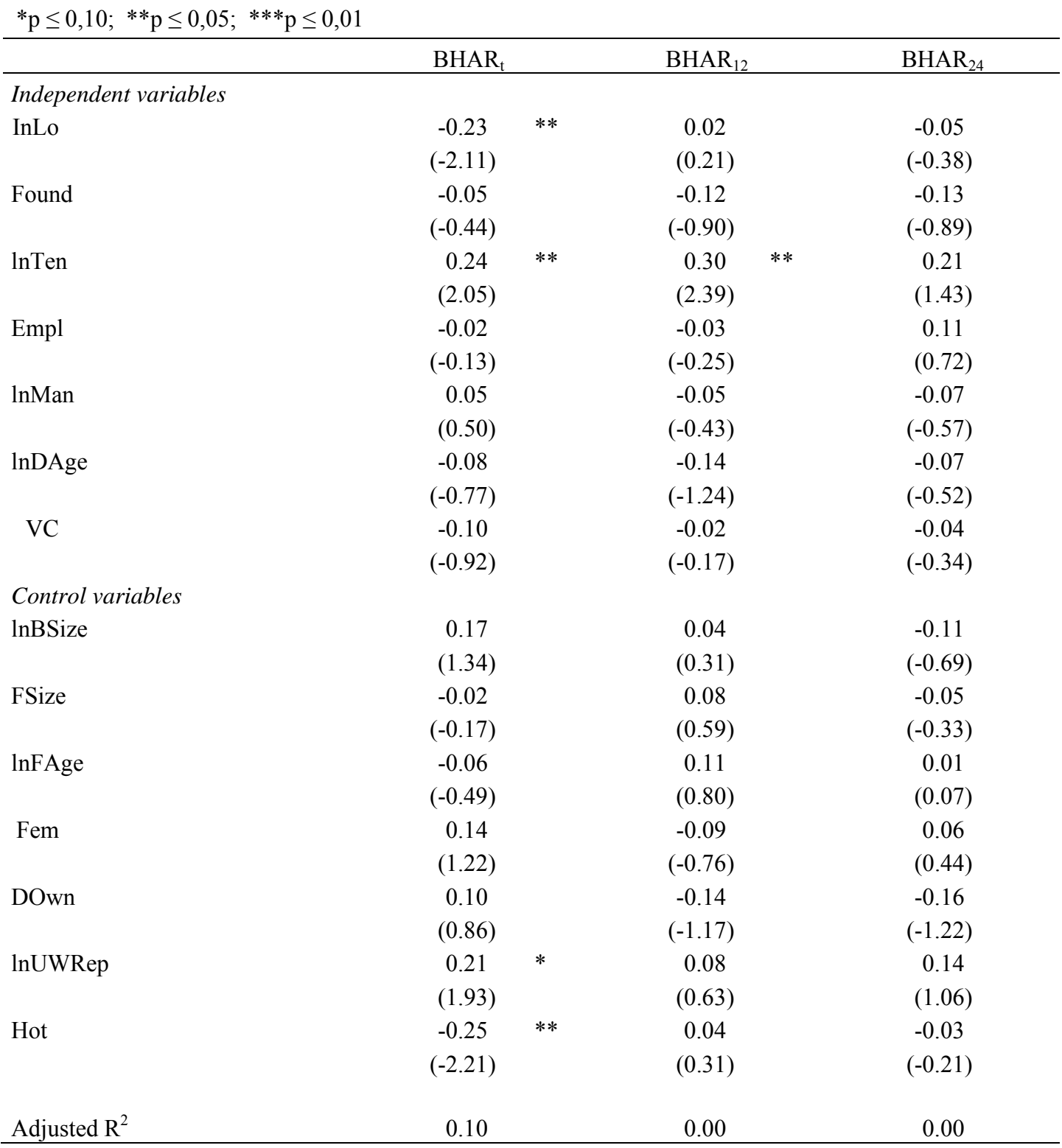

is consistent with the findings of Certo et al. (2001a). Thus, selecting board members with interlocking directorships will reduce underpricing among the IPOs who employ them. As a result, less money is left on the table and the corporation will be priced more fairly. An alternative explanation, however, for the lower underpricing associated with interlocking directorships may lie in an actual decrease in the value of the firm itself. The Swedish media has repeatedly reported that directors hold too many board seats leaving them with too little time to do a good job as directors in each firm (e.g. Danielsson 1999 and the large debate covered in Swedish media in 2009 over the numerous board seats occupied by Wanja Lundby Vedin, the head of the largest union in Sweden). If this is also the view of investors, they would place less value on a firm if many directors held a large number of interlocking directorships due to the time constraints this would place on the directors' abilities to perform 
their tasks satisfactorily. One sign that this fear exists can be found in the Swedish Code of Corporate Governance (2004:130, section 3.3) that states that each board member should not have "so many other duties that he or she is unable to devote the necessary time and care to the company's board work". If investors interpret interlocking directorships negatively as something that decreases the value of the firm a lower value would be set on it and, as a consequence there would be less room for the price to rise on the first day of trading.

Tenure is positively related to underpricing. This suggests that a stable board with longer average tenure is appreciated by first day investors but it does not reduce the extent of underpricing. Firms preparing for an IPO often restructure the board, given the need to meet listing regulations, but new directors are also recruited out of a wish to "professionalise" the board and to signal quality. These results suggest that such attempts are successful.

Only underwriter reputation and the "hot market" dummy were found to be significant in terms of the control variables' relationship with the level of underpricing. Larger degrees of underpricing were associated with hot markets and higher underwriter reputation. The model predicting the level of underpricing had a low R-square value (.10). It is evident that more factors influencing underpricing must still be added to the analysis.

\section{Long-Run Performance}

The regressions testing for a relationship between director experience and long-run aftermarket performance in twelve and twenty-four months are presented in Table 4, both produced an R-square value of zero. This suggests that the variables entered into the model have no explanatory power. Through backward regression tenure was found to have a highly significant positive relation to twelve months long-run performance but the model still produced a bad fit (R-square .05). The same analysis was undertaken for the twenty-four months long-run performance with similar results. R-square was also .05, while founder participation (a negative relationship) and tenure (a positive relationship) was found to be significant.

Because the lack of evidence of significant relationships between the independent variables and most of the dependent variables could be due to the statistical model applied, alternate statistical models were tried. Firstly, the OLS regression was expanded through the use of various interaction variables. This gave similar results to the regressions reported herein. Secondly, the changes in the dependent variable are, although significant, sometimes small. Therefore, it was believed that an ANOVA, or chi-square analysis, with the dependent variables used to classify the firms into groups of high or low aftermarket performance might be able to shed some light upon possible undetected relationships. Once again, however, the analysis offered similar results. Thus, the lack of significant relationships between investigated variables in this environment seems to be confirmed.

\section{Conclusions}

Previous research has been extended, in this study, through the testing of a large set of variables connected to director experience and included in a single model. Variables such as interlocking directorships and director age have previously been tested in conjunction with underpricing or long-run aftermarket performance but not both. Several of the variables (employee representation and founder and CEO participation) have, to the best of our knowledge, not been tested before in connection with aftermarket performance. This study has also extended the work of previous researchers in two ways given the empirical environment examined. That is, the Swedish governance paradigm is unique, combining both the stakeholder and shareholder models, and the market is dominated by a large portion of 
SMEs. Governance in SMEs has been a neglected topic for many years even though the value of a carefully selected board is said to be even higher among them (Daily et al. 2002).

Although minor similarities can be found, overall the results presented herein fail to support previous research. Certain aspects of director experience (interlocking directorships and average tenure) are found to be related to underpricing as they did in previous research. However, our results are not very strong, perhaps due to the small number of firms included in the study (122 firms) or the time period examined. In addition, none of the variables were found to have any explanatory power in terms of long-run aftermarket performance. Nevertheless, the lack of a significant relationship between director experience and long-run performance potentially has interesting implications. One reason for the lack of support of the stated hypotheses could be that smaller and larger markets react differently to governance signals. There could also be cultural differences that affect investors' valuation of certain governance characteristics.

As stated by Ho and Williams (2003:465), "under different socio-political and economic conditions, governance needs vary". Similar results were also found by Bruton et al. (2010). This highlights the need to evaluate both governance and aftermarket performance under different institutional contexts. In addition, measures of experience, other than those examined herein, may be valued more highly by Swedish investors at the time of an IPO than by Anglo-American investors, further emphasising differences caused by a diverse institutional environment. These would then have a greater influence on firm value and performance. Furthermore, the Swedish context, as discussed previously, includes regulations and guidelines that forces firms to comply with best practices of corporate governance, leading to more homogeneous boards where all contain independent directors, directors with IPO experience, etcetera. In order to create value above what the rest are doing, other contributions made by directors should be considered. Hence, further expansion of the concept of director experience is still required, especially for non-Anglo-American markets and smaller markets.

Another alternative explanation for the lack of significant relationships between director experience and long-run aftermarket performance may lie in one of the most familiar concepts in finance; the efficient market hypothesis. The board of directors is an observable signal at the time of the IPO. As argued under the efficient market hypothesis, all available information should be included immediately in the value of the stock. If the market is efficient, prices should adjust without delay to any new information. The share price reflects investors' expectations of future cash flows, and because the quality of the board is expected to influence future cash flows, and hence firm performance either directly or indirectly, this should be incorporated into the share price as soon as information regarding the board of directors becomes available. The IPO represents a unique situation because all information is usually provided well before trading starts and even though some market forces are usually involved when setting the offer price, the offer price is not set on an open market. In an efficient market any adjustments in the offer price due to board characteristics are made on the first day of trading. This would explain why a small effect of director experience can be seen on the level of underpricing while long-run performance remains unaffected. If this is the case, future studies on board and performance should focus on other measures of performance, for example market-to-book value. In addition, institutional differences in the pricing process per se could also result in differences in the aftermarket performance of IPOs.

Further research into aspects of governance that could be undertaken includes either a survey or interview approach to the experience and attitudes of directors. This would allow researchers to obtain a deeper understanding of issues related to board effectiveness and to further distinguish between process and structure. Similar ideas were put forward by Gabrielsson (2007) who found traditional board demographic measures unable to explain 
variations in CEO commitment to entrepreneurial posture. Replications of governance studies undertaken elsewhere could include a further expansion of governance concepts distilled from new empirical environments such as unregulated stock lists. As highlighted above, the institutional context seems to be influencing the importance of certain characteristics of director experience in terms of their value and effect on aftermarket performance. Thus, further examination of director experience and aftermarket performance in different institutional contexts is required to evaluate this influence, especially because markets today are changing and there are signs of a convergence towards a unified model of corporate governance including both stakeholder and shareholder perspectives. This has been particularly visible in the aftermath of the 2008 financial crisis.

\section{References}

Armstrong, JS 2001, Principles of forecasting: A handbook for researchers and practitioners, Kluwer Academic Publishers, Norwell, MA. http://dx.doi.org/10.1007/978-0-306$\underline{47630-3}$

Baker, M \& Gompers, PA 2003, 'The determinants of board structure at the initial public offering', Journal of Law and Economics, vol. 46, pp. 569-598.

http://dx.doi.org/10.1086/380409

Barry, CB, Muscarella, CJ, Peavy, JW, III \& Vetsuypens, MR 1990, 'The role of venture capital in the creation of public companies: Evidence from the going-public process', Journal of Financial Economics, vol. 27, pp. 447-471. http://dx.doi.org/10.1016/0304405X(90)90064-7

Bhabra, HS \& Pettway, RH 2003, 'IPO prospectus information and subsequent performance', The Financial Review, vol. 38, pp. 369-397. http://dx.doi.org/10.1111/1540-6288.00051

Bhagat, S \& Black, B 2001, 'The non-correlation between board independence and long-term firm performance', Journal of Corporation Law, vol. 27, pp. 231-273.

Bodnaruk, A, Kandel, E, Massa, M \& Simonov, A 2008, 'Shareholder diversification and the decision to go public', Review of Financial Studies, vol. 21, pp. 2779-2824.

http://dx.doi.org/10.1093/rfs/hhm036

Borch, OJ \& Huse, M 1993, 'Informal strategic networks and the board of directors', Entrepreneurship theory and practice, vol. 18, pp. 23-36.

Brav, A \& Gompers, PA 1997, 'Myth or reality? The long run underperformance of initial public offerings: Evidence from venture and nonventure capital-backed companies', The Journal of Finance, vol. 52, pp. 1791-1821. http://dx.doi.org/10.1111/j.1540-6261.1997.tb02742.x

Brunninge, O, Nordqvist, M \& Wiklund, J 2007, 'Corporate governance and strategic change in SMEs: The effects of ownership, board composition and top management teams', Small Business Economics, vol. 29, pp. 295-308. http://dx.doi.org/10.1007/s11187-0069021-2

Bruton, GD, Filatotchev, I, Chahine, S \& Wright, M 2010, 'Governance, ownership structure, and performance of IPO firms: The impact of different types of private equity investors and institutional environments', Strategic Management Journal, vol. 31, pp. 491-509.

Burton, B, Helliar, C \& Power, D 2004, 'The role of corporate governance in the IPO process: a note', Corporate Governance: An International Review, vol. 12, pp. 353-360.

Cai, CX, Keseay, K \& Short, H 2006, 'Corporate governance and information efficiency in security markets', European Financial Management, vol. 12, pp. 763-787.

http://dx.doi.org/10.1111/j.1468-036X.2006.00276.x 
Carpentier, C, L'Her, J-F. \& Suret, J-M 2008, 'Does securities regulation constrain small business finance? An empirical analysis', Small Business Economics, vol. 31, pp. 363377. http://dx.doi.org/10.1111/j.1468-036X.2006.00276.x

Carter, RB, Dark, FH \& Singh, AK 1998, 'Underwriter reputation, initial returns, and the long-run performance of IPO stocks', The Journal of Finance, vol. 53, pp. 285-311. http://dx.doi.org/10.1111/0022-1082.104624

Certo, ST, Daily, CM \& Dalton, DR 2001a, 'Signaling firm value through board structure: An investigation of initial public offerings', Entrepreneurship Theory and Practice, vol. 26, pp. 33-50.

Certo, ST, Covin JG, Daily CM \& Dalton DR 2001b, Wealth and the effects of founder management among IPO-stage new ventures. Strategic Management Journal, vol. 22, pp. 641-658. http://dx.doi.org/10.1002/smj.182

Certo, ST 2003, 'Influencing initial public offering investors with prestige: Signaling with board structures', Academy of Management Review, vol. 28, pp. 432-447.

Certo, ST, Holcomb, TR \& Holmes, RM Jr 2009, 'IPO Research in management and entrepreneurship: Moving the agenda forward', Journal of Management, vol. 35, pp. 1340-1378. http://dx.doi.org/10.1177/0149206309347375

Cornelius, B 2005, 'A case study of board control and governance in a venture capital portfolio company 1980-1997', The Finnish Journal of Business Economics, vol. 2, pp. 267-281.

Cowling, M 2003, 'Productivity and corporate governance in small firms', Small Business Economics, vol. 20, pp. 335-344. http://dx.doi.org/10.1023/A:1022931020438

Cressy, R \& Olofsson, C 1997, 'The financial conditions for Swedish SMEs: Survey and research agenda. Preview', Small Business Economics, vol. 9, pp. 179-195. http://dx.doi.org/10.1023/A:1007975924164

Crutchley, CE, Garner, JL \& Marshall, BB 2002, 'An examination of board stability and the long-term performance of initial public offerings', Financial Management, vol. 31, pp. 63-90. http://dx.doi.org/10.2307/3666315

Cumming, DJ \& MacIntosh, JG 2002, 'Venture capital exits in Canada and the United States', Working Paper, University of Alberta and University of Toronto.

Daboub, A, Rasheed, A, Priem, R \& Gray, D 1995, 'Top management team characteristics and corporate illegal activity’, Academy of Management Review, vol. 20, pp. 138-170.

Daily, CM \& Dalton, DR 1992, 'The relationship between governance structure and corporate performance in entrepreneurial firms', Journal of Business Venturing, vol. 7, pp. 375-386. http://dx.doi.org/10.1016/0883-9026(92)90014-I

Daily, CM, McDougall, PP, Covin, JG \& Dalton, DR 2002, 'Governance and strategic leadership in entrepreneurial firms', Journal of Management, vol. 28, pp. 387-412. http://dx.doi.org/10.1177/014920630202800307

Daily, CM, Certo, ST, Dalton, DR \& Rungpen, R 2003, 'IPO underpricing: A meta-analysis and research synthesis', Entrepreneurship: Theory and Practice, vol. 27, pp. 271-295. http://dx.doi.org/10.1111/1540-8520.t01-1-00004

Danielsson, D 1999, 'Fyrdubblat utländskt ägande i de svenska storföretagen', Svenska Dagbladet. 1 October, p. 33.

Ehrlich, SB, De Noble, AF, Moore, T \& Weaver, RR 1994, 'After the cash arrives: A comparative study of venture capital and private investor involvement in entrepreneurial firms', Journal of Business Venturing, vol. 9, pp. 67-82. http://dx.doi.org/10.1016/08839026(94)90027-2

Eisenberg, T, Sundgren, S \& Wells, MT 1998, 'Larger board size and decreasing value in small firms', Journal of Financial Economics, vol. 48, pp. 35-54.

http://dx.doi.org/10.1016/S0304-405X(98)00003-8 
EurIPO Factbook 2007, Universoft, Bergamo.

Fama, EF \& Jensen, MC 1983, 'Separation of ownership and control', Journal of Law and Economics, vol. 26, pp. 301-325. http://dx.doi.org/10.1086/467037

Filatotchev, I \& Bishop, K 2002, 'Board Composition, share ownership, and 'underpricing' of U.K. IPO firms', Strategic Management Journal, vol. 23, pp. 941-955.

http://dx.doi.org/10.1002/smj.269

Filatotchev, I 2002, 'Going public with good governance: Board selection and share ownership in UK IPO firms', Working Paper, No. 02/29. Bradford University School of Management.

Filatotchev, I 2006, 'Effects of executive characteristics and venture capital involvement on board composition and share ownership in IPO firms', British Journal of Management, vol. 17, pp. 75-92. http://dx.doi.org/10.1111/j.1467-8551.2005.00455.x

Finkle, TA 1998, 'The relationship between boards of directors and initial public offerings in the biotechnology industry', Entrepreneurship Theory and Practice, vol. 22, pp. 5-29.

Florin, J \& Simsek, Z 2007, 'The effects of moral hazard and adverse selection on the pricing and underpricing of initial public offerings', Venture Capital, vol. 9, pp. 127-143. http://dx.doi.org/10.1080/13691060601098115

Fried, V \& Hisrich, R 1995, 'The venture capitalist: a relationship investor', California Management Review, vol. 37, pp. 101-114. http://dx.doi.org/10.2307/41165791

Gabrielsson, J \& Huse, M 2002, 'The venture capitalist and the board of directors in SMEs: roles and processes', Venture Capital, vol. 4, pp. 125-146.

http://dx.doi.org/10.1080/13691060110094397

Gabrielsson, J 2007, 'Boards of directors and entrepreneurial posture in medium-size companies: Putting the board demography approach to a test', International Small Business, vol. 25, pp. 511-537. http://dx.doi.org/10.1177/0266242607080657

Gertner, R \& Kaplan, SN 1996, 'The value-maximising board', Working paper, University of Chicago and NBER.

Gilson, SC 1990, 'Bankruptcy, boards, banks, and blockholders: evidence on changes in corporate ownership and control when firms default', Journal of Financial Economics, vol. 27, pp. 355-387. http://dx.doi.org/10.1016/0304-405X(90)90060-D

Gorman, M \& Sahlman, WA 1989, 'What do venture capitalists do?', Journal of Business Venturing, vol. 4, pp. 231-247. http://dx.doi.org/10.1016/0883-9026(89)90014-1

Gouldey, B 2006, 'Uncertain demand, heterogeneous expectations and unintentional IPO underpricing', The Financial Review, vol. 41, pp. 33-54.

http://dx.doi.org/10.1111/j.1540-6288.2006.00132.x

Hartzell, JC, Kallberg, JG \& Liu, CH 2004, 'The role of corporate governance in initial public offerings: Evidence from real estate investment trusts', Working paper, The University of Texas at Austin and New York University.

Higgins, MC \& Gulati, R 2003, 'Getting off to a good start: The effects of upper echelon affiliations on underwriter prestige', Organization Science, vol. 14, pp. 244-263. http://dx.doi.org/10.1287/orsc.14.2.244.15160

Higgs, D 2003, Review of the Role and Effectiveness of Non-Executive Directors. Department of Trade and Industry, London.

Ho, C \& Williams, SM 2003, 'International comparative analysis of the association between board structure and the efficiency of value added by a firm from its physical capital and intellectual capital recourses', The International Journal of Accounting, vol. 38, pp. 465491. http://dx.doi.org/10.1016/j.intacc.2003.09.001

Howton, S 2006, 'Effect of governance characteristics on the state of the firm after an initial public offering', The Financial Review, vol. 41, pp. 419-433.

http://dx.doi.org/10.1111/j.1540-6288.2006.00150.x 
Howton, SD, Howton, SW \& Olson, GT 2001, 'Board ownership and IPO returns', Journal of Economics and Finance, vol. 25, pp. 100-114. http://dx.doi.org/10.1007/BF02759689

Huse, M 1990, 'Board composition in small enterprises', Entrepreneurship and Regional Development, vol. 2, pp. 363-373. http://dx.doi.org/10.1080/08985629000000023

Huse, M 2001, 'The hidden agenda: Exploring boards of directors', Paper prepared for the $16^{\text {th }}$ Nordiska Företagsekonomiska Ämneskonferensen, Uppsala, Scandinavian Academy of Management.

Isaksson, A 2006, 'Studies on the Venture Capital Process', Dissertation, Umeå School of Business.

Jain, BA \& Kini, O 1994, 'The post-issue operating performance of IPO firms', The Journal of Finance, vol. 49, pp. 1699-1726. http://dx.doi.org/10.1111/j.15406261.1994.tb04778.x

Jose, VR \& Winkler, RL 2007, 'Simple robust averages of forecasts: Some empirical results', International Journal of Forecasting, vol. 24, pp. 163-169. http://dx.doi.org/10.1016/j.ijforecast.2007.06.001

Kang, H, Cheng, M \& Gray, SJ 2007, 'Corporate governance and board composition: Diversity and independence of Australian boards', Corporate Governance: An International Review, vol. 15, pp. 194-207.

Kaplan, S 1998, 'The American model - Evolution or revolution', paper presented at Sitra Conference on Corporate Governance, 24 September.

Kiel, GC \& Nicholson, GJ 2003, 'Board composition and corporate performance: How the Australian experience informs contrasting theories of corporate governance', Corporate Governance: An International Review, vol. 11, pp. 189-205.

Lawless, RM, Ferris, SP \& Bacon, B 1998, 'The influence of legal liability on corporate financial signalling', Journal of Corporation Law, vol. 23, pp. 209-243.

Lerner, J 1994, 'Venture capitalists and the decision to go public', Journal of Financial Economics, vol. 35, pp. 293-316. http://dx.doi.org/10.1016/0304-405X(94)90035-3

Levinson, K 2001, 'Employee representatives on company boards in Sweden', Industrial Relations Journal, vol. 32, pp. 264-274. http://dx.doi.org/10.1111/1468-2338.00197

Loughran, T \& Ritter, JR 1995, 'The new issues puzzle', The Journal of Finance, vol. 50, pp. 23-51. http://dx.doi.org/10.1111/j.1540-6261.1995.tb05166.x

Loughran, T, Ritter, JR \& Rydqvist, K 1994, 'Initial public offerings: International insights', Pacific-Basin Finance Journal, vol. 2, pp. 165-199. http://dx.doi.org/10.1016/0927538X(94)90016-7

Lynall, MD, Golden, BR. \& Hillman, AJ 2003, 'Board composition from adolescence to maturity: A multi-theoretic view', Academy of Management Review, vol. 28, pp. 416431.

MacMillan, IC, Kulow, DM \& Khoylian, R 1989, 'Venture capitalists involvement in their investments: extent and performance', Journal of Business Venturing, vol. 4, pp. 27-47. http://dx.doi.org/10.1016/0883-9026(89)90032-3

Martin, TA 2001, 'The IPO of young, high growth SMEs on Neuer Markt', Small Business Economics, vol. 16, pp. 319-327. http://dx.doi.org/10.1023/A:1011145708342

Medoff, JL \& Abraham, KG 1980, 'Experience, performance, and earnings', The Quarterly Journal of Economics, vol. 95, pp. 703-736. http://dx.doi.org/10.2307/1885488

Megginson, W \& Weiss, K 1991, 'Venture capitalist certification in initial public offerings', Journal of Finance, vol. 46, pp. 879-903. http://dx.doi.org/10.1111/j.15406261.1991.tb03770.x

Moy, JW \& Luk, VWM 2003, 'The life cycle model as a framework for understanding barriers to SME growth in Hong Kong', Asia Pacific Business Review, vol. 10, pp. 199220. http://dx.doi.org/10.1080/13602380410001677218 
Muth, MM \& Donaldson, L 1998, 'Stewardship theory and board structure: A contingency approach', Corporate Governance: An International Review, vol. 6, pp. 5-28.

Ou, C \& Haynes, GW 2006, 'Acquisition of additional equity capital by small firms Findings from the national survey of small business finances', Small Business Economics, vol. 27, pp. 157-168. http://dx.doi.org/10.1007/s11187-006-0009-8

Pfeffer, J \& Salancik, GR 1978, The External Control of Organizations: A Resource Dependence Perspective, Harper and Row, New York.

Ritter, JR 1991, 'The long-run performance of initial public offerings', The Journal of Finance, vol. 46, pp. 3-27. http://dx.doi.org/10.1111/j.1540-6261.1991.tb03743.x

Ritter, JR 1998, 'Initial public offerings', Contemporary Finance Digest, vol. 2, pp. 5-30.

Rosenstein, S \& Wyatt, JG 1990, 'Outside directors, board independence, and shareholder wealth', Journal of Financial Economics, vol. 26, pp. 175-191. http://dx.doi.org/10.1016/0304-405X(90)90002-H

Sapienza, HJ \& Timmons, JA 1989, 'The roles of venture capitalists in new ventures: What determines their importance?', Academy of Management Proceedings, pp. 74-78.

Schuster, JA 2003, 'IPOs: insights from seven European countries', Working Paper, London School of Economics.

Söderström, HT (ed.) 2003, Ägarmakt och omvandling: Den svenska modellen utmanad, Ekonomirådets rapport 2003, SNS Förlag, Kristiansstad.

St-Pierre, J 2000, 'Can the stock market success of Montreal's IPOs be predicted by the prospectus' content?', Small Business Economics, vol. 15, pp. 15-29.

Svensk kod för bolagsstyrning, 2004, Swedish Code of Corporate Governance, Public Committee of Swedish Government Report 2004:130.

The Commission of the European Communities 2003, Recommendation 2003/361/EC.

Thorsell, A \& Cornelius, B 2009, 'Coercion, copy-cats and colleagues: Staffing the board of the IPO firm', Corporate Ownership and Control, vol. 7, pp. 108-119.

Tukey, JW 1962, 'The future of data analysis', The Annals of Mathematical Statistics, vol. 33, pp. 1-67. http://dx.doi.org/10.1214/aoms/1177704711

Westerman, JW, Geiger, SW \& Cyr, LA 2008, 'Employee equity incentives and venture capitalist involvement: Examining the effects on IPO performance', Journal of Developmental Entrepreneurship, vol. 13, pp. 409-423. http://dx.doi.org/10.1142/S1084946708001058

Yermack, D 1996, 'Higher market valuation of companies with a small board of directors', Journal of Financial Economics, vol. 40, pp. 185-211. http://dx.doi.org/10.1016/0304405X(95)00844-5

Zimmerman, MA 2008, 'The influence of top management team heterogeneity on the capital raised through an initial public offering', Entrepreneurship: Theory and Practice, vol. 32, pp. 391-414. http://dx.doi.org/10.1111/j.1540-6520.2008.00233.x 


\section{Appendix A}

Number of corporations in each industry and index used in the calculations of abnormal returns (in omitted industries there were 0 IPOs during the time period studied). All indices are based on corporations on the Stockholm Stock Exchange.

Industry classification according to GICS*

*Global Industry Classification Standard

\begin{tabular}{lrrr}
\hline & Frequency & Percent & Index \\
Materials & 1 & 0,81 & SX15PI \\
Industrials & 24 & 19,51 & SX20PI \\
Consumer Discretionary & 20 & 16,26 & SX25PI \\
Consumer Staples & 4 & 3,25 & SX30PI \\
Health Care & 15 & 12,20 & SX35PI \\
Financials & 10 & 8,13 & SX40PI \\
Information Technology & 45 & 37,40 & SX45PI \\
Telecommunication Services & 3 & 2,44 & SX50PI \\
\hline
\end{tabular}

\section{Appendix B}

Descriptive statistics, dummy variables.

\begin{tabular}{lcc}
\hline \multicolumn{3}{l}{ Distribution, dummy variables } \\
\hline \\
Found & $\mathbf{0}$ & $\mathbf{1}$ \\
Empl & $48,31 \%$ & $51,69 \%$ \\
VC & $68,60 \%$ & $31,40 \%$ \\
FSize & $56,91 \%$ & $43,09 \%$ \\
Fem & $42,50 \%$ & $57,50 \%$ \\
Hot & $76,03 \%$ & $23,97 \%$ \\
\hline
\end{tabular}


